\title{
The Reinstatement and Compensation \\ Conundrum in South African Labour Law
}

\section{J Geldenhuys*}

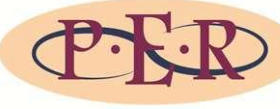

Author

Judith Geldenhuys

Affiliation

University of South Africa

South Africa

Email geldej@unisa.ac.za

Date published 27 May 2016

Editor Prof AA du Plessis

How to cite this article

Geldenhuys J "The

Reinstatement and

Compensation Conundrum in

South African Labour Law"

PER / PELJ 2016(19) - DOI

http://dx.doi.org/10.17159/1727

$-3781 / 2016 / v 19 i 0 a 1172$

Copyright

This work is licensed under a Creative Commons Attribution 4.0 International License.

DOI

http://dx.doi.org/10.17159/1727

$-3781 / 2016 / v 19 i 0 a 1172$

\begin{abstract}
The SBV Services (Pty) Ltd case brought a novel concept into the labour dispute resolution arena: arbitrators must inform employees who succeed in proving that they were dismissed for an unfair reason of the implications of a reinstatement or compensation order in terms of the Labour Relations Act 66 of 1995 before making an award. This case discussion highlights how the court, under the pennant of the interests of justice, made injudicious errors in the interpretation and application of accepted legal principles, and the potential negative effects that enforcement of this principle could have.
\end{abstract}

\section{Keywords}

Section 193 of the Labour Relations Act; section 194 of the Labour Relations Act; compensation; reinstatement; re-employment; unfair dismissal; waiver of reinstatement; non-patrimonial loss; backpay. 


\section{Introduction}

The Labour Relations Act 66 of 1995 ("LRA") provides the remedies that may be afforded to employees whose dismissals are found to be unfair. ${ }^{1}$ The primary remedy is reinstatement. ${ }^{2}$ Reinstatement ${ }^{3}$ or re-employment ${ }^{4}$ should always be ordered 5 if a dismissal is found to have been unfair, unless the affected employee does not wish to continue working for that employer; the employment relationship had deteriorated to such a degree that continued employment is rendered intolerable; it is no longer reasonably practicable for the employee to return to the position that he or she had previously filled, ${ }^{6}$ or if the dismissal was found to have been procedurally unfair only. ${ }^{7}$ Compensation should, only in these instances,

Judith Geldenhuys. LLB, LLM (UP), LLD (UNISA). Senior Lecturer in the Department of Mercantile Law, UNISA, South Africa. E-mail: geldej@unisa.ac.za. With thanks to the reviewers for their valuable inputs and fair criticism.

1 Sections 193 and 194 of the Labour Relations Act 66 of 1995 ("LRA").

2 Sections 193(1)(a) and 193(2) of the LRA. Grogan describes reinstatement as the remedy that is preferred under the current LRA and its predecessor, the Labour Relations Act 28 of 1956. In his view an employer is required to provide compelling reasons why reinstatement should not be ordered in instances where a substantively unfair dismissal occurred. Grogan Dismissal 615-616.

3 The concept "reinstate" is not defined in the labour legislation. However, it has been interpreted to mean that the unfairly dismissed employee is allowed to resume work on the same terms and conditions as before the dismissal occurred. See Grogan 2015 EL 11. In Equity Aviation Services (Pty) Ltd v CCMA 200829 ILJ 2507 (CC) para 36, the highest court found that to "reinstate" means "to put the employee back in the same job or position he or she occupied before the dismissal". It has also been understood as meaning to revive the original employment contract or to restore the status quo ante the dismissal. See for instance Mediterranean Textile Mills v SA Textile Workers Union 19986 BLLR 549 (A); Nel v Oudtshoorn Municipality 201334 ILJ 1737 (SCA).

4 The term "re-employment" is not defined in the LRA. It probably means that the employee is appointed in a new position and that the appointment does not convey the benefits that were attached to the previous position that he or she had held with the employer. In other words, a fresh employment relationship is created, which is not necessarily on the same terms as the previous engagement. See Equity Aviation Services (Pty) Ltd v CCMA 200829 ILJ 2507 (CC) para 37. Also see Consolidated Frame Cotton Corporation Ltd $v$ President of the Industrial Court; Consolidated Woolwashing and Processing Mills Ltd v President of the Industrial Court 19863 SA 786 (A). Grogan argues that re-employment was probably intended to serve as a remedy for dismissals that do not fall under the ordinary dismissals as contemplated in $s$ 186(1)(a), but rather as an exceptional remedy for cases covered by s 186(1)(b)(d). Grogan 2015 EL 15. Grogan Dismissal 620. As re-employment was not considered in the case that is being discussed, this concept is not discussed in any depth in this contribution either.

5 Notably, reinstatement is recognised as the primary remedy for the purposes of particular types of dismissal. See Billiton Aluminium SA t/a Hillside Aluminium $v$ Khanyile 20105 BLLR 465 (CC).

6 Section 193(2) of the LRA.

7 See for example Mzeku v Brand 20018 BLLR 857 (LAC), in which it was confirmed that in these instances reinstatement would be inappropriate. 
be awarded. ${ }^{8}$ However, the failings of reinstatement as a primary remedy are evident from the scarcity of orders made to this effect. Awards for the payment of compensation are far more common, although this trend clearly contrasts with the policy considerations behind the enactment of the statutory remedies. ${ }^{9}$

The setting of clearer parameters for the exercise of discretion by judges and arbitrators when making the choice between ordering reinstatement or compensation and in determining the amount of compensation would provide more legal certainty. Different courts have reached different conclusions regarding what reinstatement entails, when it is appropriate to order reinstatement, and what the contents and consequences attached to making an order of back-pay are. ${ }^{10}$ The current ambiguity regarding the interpretation to be afforded to the relevant legislative provisions ${ }^{11}$ impacts negatively on one of the most fundamental aims of the LRA: to provide access to social justice to employees who have been wronged in the employment environment. ${ }^{12}$ As matters stand, employees in labour matters have no guarantee, even if they succeed in their claims, that they will be afforded a meaningful remedy. ${ }^{13}$

The decision in SBV Services (Pty) Ltd $v$ CCMA ${ }^{14}$ attempts to bring more clarity regarding what the interpretation is that should be afforded to sections 193 and 194 of the LRA, in particular in the case of dismissals that are found to have been affected for an unacceptable reason (those that are substantively unfair). The aim of this contribution is to analyse the criteria that the court seems to have laid down for these purposes for use by CCMA commissioners when assessing what remedy to impose. A closer investigation into how the decision was arrived at by the court, and

Van Heerden and Coetzee 2011 De Jure 479.

See the discussion under 4.2 below.

10 See Grogan's insightful discussion of two recent judgments, Myers $v$ National Commissioner of the SA Police Service $2013 \mathrm{JOL} 30564$ (SCA) and Themba $v$ Mintroad Sawmills 20152 BLLR 174 (LC), in which he analyses the different interpretations afforded by the courts to the undefined concepts of "reinstatement", "position", and "back-pay" in Grogan 2015 EL.

11 Sections 193 and 194 of the LRA.

12 Section 1 of the LRA. The Constitution of the Republic of South Africa, 1996 ("the Constitution"), in s 34 thereof, also guarantees that all South African citizens have the right to have their disputes heard and resolved in a forum that is unbiased.

13 See, for instance, the discussion of the determination of the quantum of compensation under 4.5.1.

14 SBV Services (Pty) Ltd v CCMA 201334 ILJ 996 (LC) ("SBV Services (Pty) Ltd case"). As the CCMA award dated 22 February 2010 is unreported, references to the award and specific facts that are not pertinent to the discussion are omitted. All references to paragraphs pertain to the Labour Court review. The author can be contacted for further details concerning the arbitration award. 
consideration of the possible impact of the court's findings, exposes the fact that this decision does the opposite of providing legal certainty. If it is heeded as precedent, it could in fact lead to unconscionable unfairness.

\section{The facts}

The salient facts of this matter are as follows: The respondent-employee had been dismissed after the applicant-company suffered a significant loss that it had found, in a subsequent disciplinary enquiry, could be directly attributed to gross negligence in the respondent-employee's performance of his duties. ${ }^{15}$ However, the proven facts did not in the CCMA commissioner's view support this finding. As a result, the dismissal was found to have been substantively unfair in the CCMA. Having decided that the employee was legally entitled to a remedy for unfair dismissal under the LRA, the commissioner was required to decide what remedy would be appropriate in the particular circumstances. On the facts it appears that initially the employee had sought reinstatement as a remedy. However, after the commissioner unsuccessfully attempted to mediate a settlement between the parties, the employee asked for the maximum compensation amount: twelve months' pay as compensation. At the end of the hearing, the commissioner again enquired from the respondent-employee what remedy he would prefer. He again elected compensation instead of reinstatement, indicating that he needed money to pay for his motor vehicle and that he felt that his reputation in the workplace would have been tarnished because of the serious allegations that had been made against him by the employer. ${ }^{16}$

The commissioner awarded an amount of nine months' remuneration as compensation. ${ }^{17}$ The employer was dissatisfied with the outcome and referred the award on review, requesting the Labour Court to reverse the finding that the dismissal had been substantively unfair as well as the compensation award that had been made. ${ }^{18}$

\section{The judgment}

The Labour Court was satisfied with the commissioner's conclusion that the dismissal had been substantively unfair. ${ }^{19}$ As the Labour Court agreed

SBV Services (Pty) Ltd case para 4.

SBV Services (Pty) Ltd case para 32.

SBV Services (Pty) Ltd case paras 2, 48(b).

SBV Services (Pty) Ltd case paras 5, 10, 13, 31.

SBV Services (Pty) Ltd case paras 3-30. 
with the CCMA commissioner's finding that the employee had been dismissed in the absence of a fair reason, further details of the merits relating to the fairness of the dismissal are omitted.

Nevertheless, the compensation order in the amount of nine months' remuneration that the commissioner had made was set aside. ${ }^{20}$ The reason for this was that the Labour Court had a problem with the way in which the decision regarding the appropriate remedy had been arrived at in the CCMA. As a result, the matter was reverted to that forum in order to allow the CCMA commissioner another opportunity to revisit the remedyaspect after properly informing the respondent-employee of what the different remedies for unfair dismissals in the LRA entail. ${ }^{21}$

Although, as already said, the employee had been afforded no less than three opportunities in the CCMA to select which remedy he would prefer and he had not asked for further explanations regarding the different options, the court felt that the arbitrating commissioner neglected to explain properly the consequences of each available remedy. ${ }^{22}$ In the court's view this was enough reason to find that the employee, who had opted twice for compensation to be paid to him instead of his being reinstated, had not waived his right to be granted the primary remedy. The court further expressed the view that if the commissioner had explained the consequences of the different remedies better to the employee, particularly that a reinstatement order could be made retrospectively or with "back-pay," he would most probably have opted to be reinstated instead of choosing to be paid an amount of compensation. The court bolstered this finding by raising the reason that the respondent-employee had given as a reason for making his choice that he needed money to pay for his car, and he felt that his reputation in the workplace would have suffered a serious blow. ${ }^{23}$

The CCMA commissioner had in the court's view misunderstood the purpose of compensation as a remedy under the LRA because he had not interjected after hearing the reasons that the employee gave for choosing compensation. The reasons provided for choosing compensation, in the Labour Court's opinion, exposed the misconception that the respondentemployee was under: that compensation was due to him based on the

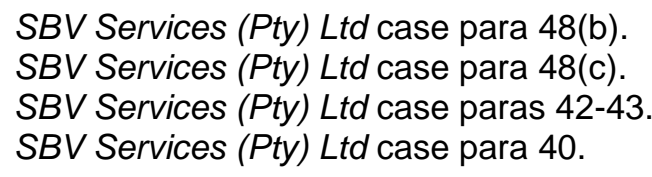


injury that had been caused to his reputation resulting from the serious allegations that had been made by the employer. ${ }^{24}$

The fact that reinstatement is the primary remedy is one of the things that the court said should be explained to an unfairly dismissed employee. In addition, it should be explained that "reinstatement" entails the opportunity for the unfairly dismissed employee to resume work and also to receive payments that he or she would have been entitled to if the unfair dismissal had not taken place. The court found further that no claims are possible in respect of non-patrimonial loss, or for income that was lost, if compensation is preferred as a remedy. It was acknowledged by the court that compensation awards are subject to the limitations set in the legislation. However, the retrospective effect afforded to a reinstatement award, or "back-pay", can exceed the limitations. ${ }^{25}$

The matter was referred back to the CCMA for determination of the remedy after a proper explanation of these concepts had been provided to the unfairly dismissed employee. ${ }^{26}$ Memani AJ ordered the parties to bear their own legal costs for the proceedings in the Labour Court. ${ }^{27}$

\section{Comments}

\subsection{Introduction}

A number of important aspects are touched on in SBV Services (Pty) Ltd: Firstly, when should presiding officers award compensation instead of reinstating or ordering the re-employment of an employee to remedy an unfair dismissal? Secondly, what is understood by the terms "reinstatement," "back-pay" and "compensation"? Finally, to what extent should an employee who had been unfairly dismissed be informed of the nature and consequences attached to the different remedies provided under the LRA, and by whom? These questions are answered under separate headings below.

\subsection{The policy considerations behind reinstatement as a remedy}

In order to answer the first question, it is necessary to scrutinise the policy considerations for the introduction of the different remedies in the LRA, as well as for the limits placed on the remedy of compensation. That

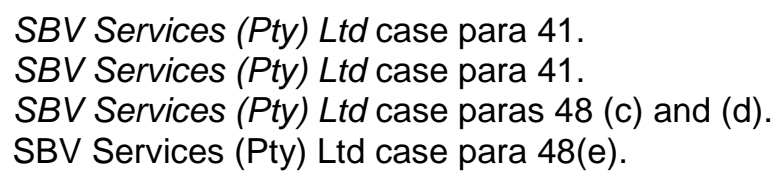


reinstatement would be the primary remedy was decided upon by organised labour, business and the government after considering the problems related to harsh, limitless compensation awards that were being made and the high levels of unemployment under the previous labour law regime. Organised labour was opposed to the use of remedies other than reinstatement or re-employment as it felt that, except in certain specified situations, workers should be given back their jobs if they had been dismissed unfairly. Furthermore, in the interest of economic development and fairness it was acknowledged by the role-players that it should not be possible for forums to make huge compensation awards against employers. As a result the compensation awards had to be capped. ${ }^{28}$

Section 193 of the LRA determines:

(1) If the Labour Court or an arbitrator appointed in terms of this Act finds that a dismissal is unfair, the Court or the arbitrator may-

(a) order the employer to reinstate the employee from any date not earlier than the date of dismissal;

(b) order the employer to re-employ the employee, either in the work in which the employee was employed before the dismissal or in other reasonably suitable work on any terms and from any date not earlier than the date of dismissal; or

(c) order the employer to pay compensation to the employee.

(2) The Labour Court or the arbitrator must require the employer to reinstate or re-employ the employee unless-

(a) the employee does not wish to be reinstated or re-employed;

(b) the circumstances surrounding the dismissal are such that a continued employment relationship would be intolerable;

(c) it is not reasonably practicable for the employer to reinstate or re-employ the employee; or

(d) the dismissal is unfair only because the employer did not follow a fair procedure.

(3) If a dismissal is automatically unfair or, if a dismissal based on the employer's operational requirements is found to be unfair, the Labour Court in addition may make any other order that it considers appropriate in the circumstances.

28 Explanatory Memorandum for the Labour Relations Amendment Bill (1995) 16 ILJ 278, 316, 320. Also see Kroukam v SA Airlink (Pty) Ltd 200526 ILJ 2153 (LAC) paras $115,116$. 
(4) An arbitrator appointed in terms of this Act may determine any unfair labour practice dispute referred to the arbitrator, on terms that the arbitrator deems reasonable, which may include ordering reinstatement, re-employment or compensation.

Section 194(1) of the LRA reads:

The compensation awarded to an employee whose dismissal is found to be unfair either because the employer did not prove that the reason for dismissal was a fair reason relating to the employee's conduct or capacity or the employer's operational requirements or the employer did not follow a fair procedure, or both, must be just and equitable in all circumstances, but may not be more than the equivalent of 12 months' remuneration calculated at the employee's rate of remuneration on the date of dismissal.

Sections 193(2) and 194 of the LRA plainly envisage giving effect to the wishes of organised labour: An employee who was unfairly dismissed must be reinstated, ${ }^{29}$ unless one of the exceptions applies ${ }^{30}$ and the amount of compensation that can be awarded is capped. ${ }^{31}$ To give an employee back his or her job would be first prize, whereas compensation was intended to be an exceptional remedy. ${ }^{32}$

Although the legislative intent seems quite clear, in drafting the LRA there were already concerns regarding reinstatement as the primary remedy. The main reason for apprehension at that time has been proven true: Reinstatement is a suitable remedy only if labour disputes are resolved expeditiously, which is often not the case in South Africa. ${ }^{33}$ The result is that reinstatement as the primary remedy is not strictly enforced as such by the labour forums. ${ }^{34}$ Due to the fact that the legal battles are often protracted, the positions that the unfairly dismissed employees had filled

29 Bhorat and Cheadle 2010 http://www.dpru.uct.ac.za/sites/defaults/files.site/ default/files/DPRU\%20PB\%2010-27.pdf 23; Van Niekerk 2007 http://www.dpru. uct.ac.za/sites/default/files/image_tool/images/36/DPRU\%20WP07-119.pdf 19; Van Heerden and Coetzee 2011 De Jure 479; Tshongweni v Ekurhuleni Metropolitan Municipality 201233 ILJ 2847 (LAC) para 31

30 Mzeku v Volkswagen SA (Pty) Ltd 200122 ILJ 1575 (LAC) paras 77-79; Mediterranean Textile Mills (Pty) Ltd v SA Clothing \& Textile Workers Union 201233 ILJ 160 (LAC) para 28.

31 Kroukam v SA Airlink (Pty) Ltd 200526 ILJ 2153 (LAC) paras 117, 118. In this case, the LAC acknowledged that the test that should be used to determine the amount of compensation should not be the same as for delictual damages and that the amounts should, therefore, not be open-ended.

32 Mzeku Volkswagen SA (Pty) Ltd 200122 ILJ 1575 (LAC) paras 77-79; Mediterranean Textile Mills (Pty) Ltd v SA Clothing \& Textile Workers Union 201233 ILJ 160 (LAC) para 28.

33 Sidumo v Rustenburg Platinum Mines Ltd 200728 ILJ 2405 (CC) para 44. Also see Vettori 2013 SA Merc LJ 245.

$34 \quad$ Tshongweni v Ekurhuleni Metropolitan Municipality 201233 ILJ 2847 (LAC) para 33; Kroukam v SA Airlink (Pty) Ltd 200526 ILJ 2153 (LAC) para 116. 
are often already occupied. The animosity resulting from labour proceedings also often leads to a degree of deterioration in the working relationship which would render it inadvisable to reinstate or order the reemployment of the employee in the workplace.

Compensation as a remedy was intended to provide a measure of solace for unfairly dismissed employees ${ }^{35}$ when it would be unreasonable or impractical to reinstate or re-employ them. ${ }^{36}$ Although it had been conceded to by organised labour that there should be limits placed on the amount of compensation that can be awarded in instances where reinstatement is impracticable in order to avoid negative consequences on the commercial viability of employers, allowing such a restriction has been described as a major "concession and sacrifice" on the part of employees. ${ }^{37}$

In a nutshell, long delays in the resolution of labour disputes detract from the legitimacy of the legal system and negate the value of the remedies in the LRA to such an extent as to disavow it as a protection mechanism. This acknowledged short-coming detracts from the legitimacy of litigation as an alternative to industrial action. ${ }^{38}$

Courts and other labour forums must interpret sections 193 and 194 of the LRA purposively in a way which gives effect to the agreement that was reached by the various role-players who participated in negotiating its

35 Mischke 2005 CLL 24.

36 Johnson \& Johnson (Pty) Ltd v CWIU 199920 ILJ 89 (LAC) para 41; Minister of Justice and Constitutional Development v Tshishonga 200930 ILJ 1799 (LAC) para 18. Davis JA determined that the court is guided by jurisprudence relating to the award of solatium in terms of the actio iniuriarem. Factors considered in determining the amount of compensation which would be just and equitable include the degree of humiliation and indignity suffered by the employee. The award determined ultimately falls within the discretion of the court.

37 Kroukam v SA Airlink (Pty) Ltd 200526 ILJ 2153 (LAC) para 116.

38 In Sidumo $v$ Rustenburg Platinum Mines Ltd 200728 ILJ 2405 (CC), the Constitutional Court noted that this unfair dismissal case had taken longer than seven years to resolve. This court felt that the delay was unacceptable as it detracted from the legal effect of the statutory remedies and drew the legitimacy of the legislation into question. Statistics and reported case law unfortunately show that this case is not so exceptional. See for instance Stevenson $v$ Sterns Jewellers (Pty) Ltd 19867 ILJ 318 (IC) 325; PG Group (Pty) Ltd v Mbambo 20051 BLLR 71 (LC) para 29; Nathan $v$ the Reclamation Group (Pty) Ltd 200223 ILJ 588 (CCMA) 601C$D$. This has resulted in a tendency that has developed contrary to the legislative goal. The Tokiso Report for 2009 and 2010 indicated that only about $36 \%$ of successful applicants are reinstated into their previous positions. Friedman et al Tokiso Dispute Settlement 47. 
content. $^{39}$ To ensure that a balance is struck between limiting the compensation that can be awarded and the right of employees who are unfairly dismissed to social justice requires use of the correct tests to establish compensation amounts. ${ }^{40}$

In applying these principles to the SBV Services (Pty) Ltd case, the court was correct in recognising that reinstatement is the primary remedy. However, the legislative purpose of section 194 of the LRA would be undermined if an order of reinstatement were to be made with retrospective effect extending beyond the restrictions on the amount of compensation. Even if the employee in the SBV Services (Pty) Ltd case did not wish to be reinstated, or in actual fact made no mistake when electing compensation, he would now be allowed to claim reinstatement with back-pay resulting in an order extending beyond the statutory compensation limits. The employee could then resign. ${ }^{41}$ Otherwise, the employee could return to work for the employer and to earn a salary, and if the working situation was - as he predicted - intolerable because of the serious allegations that had been made against him previously, he could even refer another dispute to the CCMA. It has long been accepted that employers are required to protect employees from physical and psychological harm. If an employee can prove that the employer had failed to take reasonable steps to prevent harm to his or her dignity, a claim based on constructive dismissal could ensue. ${ }^{42}$ Should this claim succeed, the cycle could continue. This anomaly could perhaps be overcome by interpreting section 193 of the LRA to the effect that the retrospectivity of a reinstatement order (or back-pay) is subject to the statutory limitations - 24 months or twelve months, whichever is the earlier - in order to harmonise sections 193 and $194 .{ }^{43}$

39 Kroukam v SA Airlink (Pty) Ltd 200526 ILJ 2153 (LAC) para 115. Also see Grogan Dismissal 617. Arbitrators should be careful not to be too imaginative in making awards and in so doing not to exceed the bounds that have been laid down.

40 The purpose of compensation is discussed further under 4.5.

41 This realistic fear was contemplated by the court, too. See Zondo J's reasoning in the minority judgment in Kroukam v SA Airlink (Pty) Ltd 200526 ILJ 2153 (LAC). It was also evident from the way in which the order was framed in NUMSA $v$ Edelweiss Glass and Aluminium (Pty) Ltd 200911 BLLR 1083 (LC).

42 See for instance Media 24 Ltd v Grobler 200526 ILJ 1007 (SCA) para 65; Vettori 2012 PELJ 113-114, 116-117.

43 Zondo JP (as he was then) in his minority judgment in Kroukam v SA Airlink (Pty) Ltd 200526 ILJ 2153 (LAC) para 126. 


\subsection{Being informed regarding the consequences of the LRA's remedies}

In the SBV Services (Pty) Ltd case, the Labour Court made it clear that in all instances where employees succeed in proving that the dismissal was not affected for a reason that is accepted as being fair under the LRA, ${ }^{44}$ it would be in the interest of justice to properly inform the affected employee of the different remedies: re-instatement with retrospective force, or compensation subject to the statutory restrictions. The arbitrator in this particular case was directed to comply with paragraph 45 of the Labour Court's judgment before making his or her final determination. ${ }^{45}$ The relevant segment of the judgment reads:

In my view the interest of justice require that in all unfair dismissal cases where a finding has been made that the dismissal of the employee is substantively unfair, the arbitrator or the court must inform the employee that:

(1) The law enjoins the arbitrator or the court to reinstate him/her;

(2) Reinstatement means that he/she will be entitled to resume employment, and in addition he/she has become entitled to his/her wages and other moneys that he/she would have been paid during the period of his/her unfair dismissal. The word "backpay" should be avoided;

(3) He/she may elect compensation, but compensation is not in respect of non-patrimonial loss, nor is it for lost income, in a language and a manner which is suitable for the employee's station in life;

(4) He/she may be awarded an amount in money that does not exceed the threshold that is applicable in his/her case. ${ }^{46}$

The Labour Court continued to state that the duty to inform applies to both represented and unrepresented employees whose dismissals were found to have been substantively unfair. Furthermore, it would seem as if the court was of the opinion that the standard of the communication to the affected employee would also be made subject to close scrutiny. ${ }^{47}$

Requiring arbitrators to inform employees of the nature and effect of remedies before making an award is a dubious concept. It raises many questions: Would arbitrator's need to explain the different remedies in the employee's home language? To what extent should assurance be made

\footnotetext{
44 Reasons related to the employee's conduct or capacity, or to the operational requirements of the employer. See item 2.1 of the Code of Good Practice: Dismissal in Schedule 8 to the LRA.

45 SBV Services (Pty) Ltd case para 48(d).

$46 \quad$ SBV Services (Pty) Ltd case para 45.

47 SBV Services (Pty) Ltd case para 46.
} 
that the standard of the explanation meets the mark that has been set by the Labour Court? Would the arbitrator need to ascertain whether the employee actually understands the difficult legal concepts correctly?

There are eleven official languages in the Republic of South Africa: Pedi, Sotho, Tswana, Swati, Venda, Tsonga, Afrikaans, English, Ndebele, Xhosa and Zulu. ${ }^{48}$ The Constitution ${ }^{49}$ further requires that the use of language must be monitored and regulated by legislation and other means and that they should be treated with "parity of esteem" and "equitably".

The CCMA does have appointed interpreters. The Rules of Conduct of Proceedings before the CCMA also provides specifically for the possibility of having an interpreter available if consensus is reached between the parties at a pre-arbitration conference that this is required. ${ }^{50}$ However, the competence of the interpreters to explain technical legal principles that even judges seem to misinterpret may be drawn into question.

In addition, enforcing a general duty on CCMA arbitrators to explain these concepts properly before being able to make a binding and enforceable award ${ }^{51}$ would most probably fall outside the scope of capacity constraints and the CCMA's aim of resolving labour disputes in a non-formalistic way. ${ }^{52}$ There may be even more reviews, causing further delays in the resolution of labour disputes. ${ }^{53}$

The high frequency of referrals of CCMA awards on review and the resultant delays in the resolution of labour disputes are issues of concern for the legislature. One of the aims of the Labour Relations Amendment $A c t^{54}$ is to ensure that delays in the resolution of labour disputes are restricted. ${ }^{55}$ One measure that has been introduced in order to achieve

48 Item 6 of the Founding Provisions in the Constitution.

49 Section 6(4) of the Constitution.

50 Rule 20(r) of the Rules of Conduct of Proceedings before the CCMA.

51 In terms of $S$ 143(1) of the LRA, unless an award is an advisory one, an award made by the CCMA commissioner would be final and binding and have the same power as a judgment that was handed down by the Labour Court. In setting a requirement that a proper explanation has to be provided, it would seem as if in the absence of such an explanation an award would not be binding, as it would fall subject to the supervisory or review powers of the Labour Court.

52 The LRA expressly aims to provide for simple non-formalistic measures of dispute resolution. See the preamble to the LRA as well as the Explanatory Memorandum for the Labour Relations Amendment Bill (1995) 16 ILJ 278.

53 Waglay 2003 ILJ 1228.

54 Labour Relations Amendment Act 6 of 2014.

55 Department of Labour 2012 https://www.labour.gov.za/downloads/legislation/ bills/proposed-amendment-bills/memoofobjectslra.pdf 13. S 145 of the Labour Relations Amendment Act 6 of 2014 sets new time limits in which review 
this and to restrict the number of reviews is making referrals of matters that would not finalise the dispute exceptional. ${ }^{56}$ Employers who take matters on review are also required to pay an amount of money in security to suspend the arbitration award for the time that it takes to finalise the review. ${ }^{57}$ Obviously, all these measures have been implemented to address the fact that taking CCMA awards on review has become commonplace.

Consistent interpretation of the legal terms is required. In order to contribute to legal certainty in the making of awards, the terms "compensation", "reinstatement" and "back-pay" would have to be consistently interpreted. There is precedent in evidence of the way in which the court has construed these legal terms in mainly one of the eleven official languages. This is elaborated upon below.

\subsection{The discretion of presiding officers to decide on the remedy}

Although the Labour Court in SBV Services (Pty) Ltd was correct in holding that labour forums should give preference to reinstatement as a remedy instead of awarding compensation, section 194 of the LRA does not indicate when and why compensation should be awarded rather than ordering reinstatement. ${ }^{58}$ Presiding officers have discretion to decide on what remedy is appropriate. ${ }^{59}$ Ultimately they have to assess the facts and decide what is fair and reasonable in the particular circumstances. ${ }^{60}$

Section 194 provides guidelines as to how much compensation should be awarded. Whereas courts previously enjoyed an unfettered discretion regarding the amount of compensation awarded this is no longer the case. ${ }^{61}$ The LRA places significant limitations on the compensation awards that presiding officers may order. ${ }^{62}$ For an ordinary dismissal the limit is

applications must be heard in the Labour Court and for handing down judgment in reviews.

56 Section 157 of the Labour Relations Amendment Act 6 of 2014.

57 Section 145(8) of the Labour Relations Amendment Act 6 of 2014.

58 Cohen 2003 ILJ 739.

59 Kylie v CCMA 201031 ILJ 1600 (LAC) para 52. Davies AJ discusses the considerable discretion that presiding officers enjoy.

60 Vettori Employment Contract 84-87. Also see NUM v East Rand Gold \& Uranium Co Ltd 199112 ILJ 1221 (A) 1237G-H; Dimatteo 1997 SC L Rev 343-353 provides an explanation for the reasoning that presiding officers' subjective opinions play a role in the application of the reasonable man test.

61 Vettori 2012 PELJ 105; Van Heerden and Coetzee 2011 De Jure 479.

62 Section 194 of the LRA. 
set at twelve months' remuneration and for automatically unfair dismissals ${ }^{63} 24$ months' pay cannot be exceeded. ${ }^{64}$

How much compensation is awarded under the LRA is open to judicial discretion. ${ }^{65}$ In deciding on a quantum various factors must be considered: whether the dismissal was substantively or procedurally unfair or both, the degree of deviation from the prescribed procedural requirement if applicable; the consequences to the parties; and conduct by either party that undermines any of the objects of the LRA or the effective resolution of the dispute. Even if an employee suffered no financial harm, compensation may still be awarded. The amount of patrimonial loss that was suffered remains relevant in this enquiry, but it is not conclusive in determining the amount. ${ }^{66}$

In SBV Services (Pty) Ltd the CCMA commissioner decided to award an amount equal to nine months' wages to the employee as compensation. This fell within the commissioner's discretion to do. In assessing the

63 Section 187 of the LRA determines that a dismissal will be automatically unfair if the reason for dismissal is one or more of the following: the employee joined a trade union; the employee exercised a right in terms of the LRA; the employee disclosed protected information; the employee participated in a protected strike, protest action or refused to work during a protected strike or lock-out; to compel an employee to accept a demand in a matter of mutual interest; the employee took action against the employer which he was entitled to take; the pregnancy of the employee or related reasons; discrimination by the employer against the employee; a transfer contemplated in terms of $\mathrm{s} 197 / 197 \mathrm{~A}$. Although HIV is not listed in $\mathrm{s} 187$, the Code of Good Practice: Key Aspects of HIV/AIDS and Employment para 5.3.4 refers to s 187 when it declares that an employee may not be dismissed simply because he or she is HIV-positive. See SA Chemical Workers Union v Afrox Ltd 199920 ILJ 1718 (LAC) para 32 with regard to the approach followed by the courts in the application of $s$ 187(1)(a) of the LRA (discrimination for joining a trade union). See Jabari $v$ Telkom SA (Pty) Ltd 200627 ILJ 1854 (LC) 1869, where an employee was held to have been unfairly dismissed in terms of $S 187(1)(d)$ as the dominant reason for the dismissal was the fact that the employee had referred an unfair labour practice dispute. See Solidarity obo McCabe v SA Institute for Medical Research 20039 BLLR 927 (LC); Vorster $v$ Rednave Enterprises CC t/a Cash Converters Queenswood 200930 ILJ 407 (LC) para 27; Nieuwoudt v All-Pak 200930 ILJ 2444 (LC) 2460 with regard to an application of $s$ 187(1)(e) (discrimination based on pregnancy). See generally Tshishonga $v$ Minister of Justice and Constitutional Development 20074 BLLR 327 (LC) paras 86, 95 et seq; Pedzinski v Andisa Security (Pty) Ltd 20062 BLLR 184 (LC) for an application in terms of $\mathrm{s} 187(1)(\mathrm{h})$ (dismissal for making a protected disclosure).

64 Vorster v Rednave Enterprises CC t/a Cash Converters Queenswood 200930 ILJ 407 (LC) 420F.

65 Fouldien v House of Trucks (Pty) Ltd 200223 ILJ 2259 (LC) para 16.

66 Lakomski v TTS Tool Technic Systems (Pty) Ltd 200728 ILJ 2775 (LC); Fouldien v House of Trucks (Pty) Ltd 200223 ILJ 2259 (LC) 2264; National Industrial Workers Union v Chester Wholesale Meats KZN (Pty) Ltd 200425 ILJ 1293 (LC); Pretoria Society for the Care of the Retarded v Loots 199718 ILJ 981 (LAC) 989-991; Ferodo (Pty) Ltd v De Ruiter 199314 ILJ 974 (LAC) 981C-981G. 
factors when deciding on the most appropriate remedy there is no specific check list or rules. The commissioner asked the employee what remedy he would prefer and the employee chose compensation. The commissioner considered the maximum compensation of twelve months' pay that the employee asked for as being too much. This shows that the commissioner also considered what would be fair to the employer when he set the amount of compensation to be paid.

If the employee should again elect compensation as remedy, the chances are very good that the award amount will not be increased substantially, as it is exceptional for the maximum amount of compensation to be awarded. ${ }^{67}$ In any event, the commissioner had already expressed the view that twelve months' remuneration as compensation would be too much. 68

\subsection{The meaning of "compensation"}

In SBV Services (Pty) Ltd "compensation" was described as meaning "the remuneration which may be paid to an employee in lieu of reinstatement to a maximum of 24 months". ${ }^{69}$ This definition is flawed for at least two reasons: firstly, it is a strange mutation of two distinct legal concepts, compensation and reinstatement. Second, it is at least inaccurate, overgeneralised, or wrong in setting the limit at 24 months. The 24 month maximum award applies only in respect of dismissals that are automatically unfair and not to all types of dismissal. ${ }^{70}$

Statutory compensation has previously been described by others as being a payment made to an employee to "make good a loss resulting from an unfair labour practice"71 and as "solace payment [which is made] to the employee for an infringement of the employee's right not to be unfairly dismissed". ${ }^{72}$

67 Tshishonga $v$ Minister of Justice and Constitutional Development 20074 BLLR 327 (LC). In 2009/2010 the average arbitration compensation amount was under R50 000. This amount increased slightly to R50 587,97 for the first few months of 2011. Compensation amounts are usually much less than the maximum claim amount for claims that are entertained by the Magistrate's Court. Friedman et al Tokiso Dispute Settlement 47; Benjamin and SBP 2010 http://www.labour.gov.za/DOL/downloads/ documents/useful-documents/labour-relations/RIA13Sept2010.pdf 108.

68 SBV Services (Pty) Ltd case para 32.

69 SBV Services (Pty) Ltd case para 38.

70 Section 194(3) of the LRA.

71 Amalgamated Beverages Industries v Jonker (Pty) Ltd 199314 ILJ 1232 (LAC) $1256 \mathrm{G}$

72 Mischke 2005 CLL 24. 
The Labour Court had endorsed the CCMA commissioner's finding that the dismissal qualified as one which had been substantively unfair, but did not find that it had been automatically unfair. Therefore, it would clearly attract only the maximum award amount of twelve month's remuneration. ${ }^{73}$ Obviously, this makes a major difference in respect of what the final outcome of this matter may be.

The Labour Court in SBV Services (Pty) Ltd makes a blunt attempt at describing what compensation for unfair dismissal implies when it states that compensation is not the same as damages for the reparation of losses suffered whether patrimonial or non-patrimonial. ${ }^{74}$ In addition, the court's premise that the employee did not understand the nature of a reinstatement award because he had opted for compensation to enable him to pay for his car is in my opinion, flawed. The nine months compensation would possibly have enabled the employee to pay off his car. If the employee had been disgruntled by the outcome, he could have taken the matter on review. He did not.

The fact that his reputation in the workplace would have been tarnished is also not in my view an argument supporting the fact that the employee misconstrued the nature of compensation as a remedy. On the contrary, this indicates that the employee understood that he would be placed back in a situation he would find uncomfortable if reinstatement was ordered. The judge's interpretation that the compensation was being considered as a solatium for the iniuria suffered and its statement in paragraph 38 of the judgment ${ }^{75}$ is in my view incorrect. If the employee was indeed as ignorant of the law as the judge suspects, he would not have contemplated this possibility either. More than likely he was considering what it would be like to return to work with the dark cloud of having instituted legal action against the employer in order to be able to return still hanging over his head. It is also very likely that, as he had said, his colleagues would have formed their own views regarding his guilt and that he would long bear the brunt of the serious allegations that had been made against him, albeit disproved or unaccepted in the CCMA.

Furthermore, some similarities exist between compensation and damages. Patrimonial losses that were suffered resulting from the unfair conduct are

Also see Van Heerden and Coetzee 2011 De Jure 480.

SBV Services (Pty) Ltd case para 38; Visser and Potgieter Law of Damages 20.

In the SBV Services (Pty) Ltd case para 41 Memani AJ expresses his concern regarding the perceived misconception that the respondent-employee had been under. 
relevant in establishing the amount of compensation. In labour disputes, as in a case where damages are calculated, employees must attempt to mitigate their losses. ${ }^{76}$ The connection that is made in section 194 of the LRA between the limitation of compensation and the remuneration that the dismissed employee received at the time of dismissal also implies that courts have to consider the loss of income when determining the compensation amount.

In terms of the actio iniuriarum, money is also paid to the victim as a solatium. ${ }^{77} \mathrm{~A}$ solatium in case of the impairment of a personality right is intended to bring some solace to him or her in the form of damages. The term "solatium" has a punitive connotation. A solatium does not remedy the actual insult or injury, although it does suggest the need for penance or an act of retribution. ${ }^{78}$ Even though the motivation for an award of compensation is usually to compensate the unfairly dismissed employee, at times it also serves a punitive function. ${ }^{79}$ If an employer's conduct in terminating an employee's services negatively impacted on the employee's dignity, this would usually be the case. ${ }^{80}$

Solatium as applied under the actio iniuriarum and in terms of section 194(1) of the LRA both entail ordering the perpetrator to pay to the victim an amount of money for the infringement of a right. Both the rights that the legislation seeks to protect in terms of the action for iniuria and the unfair dismissal remedy are connected to the right to human dignity and

76 Grogan Dismissal 635-636. In Myers v Abrahamson 19523 SA 121 (C) 127 it was held that an employee is entitled to an amount of compensation "...less any sum he earned or could reasonably have earned during such latter period in similar employment".

77 Minister of Justice and Constitutional Development v Tshishonga 200930 ILJ 1799 (LAC) para 18.

78 See for instance Masawi v Chabata 19914 SA 764 (ZH) 772.

79 See for instance Adams v Coin Security Group (Pty) Ltd 199920 ILJ 1192 (LC); Chemical Energy Paper Printing Wood \& Allied Workers Union $v$ Glass \& Aluminium 2000 CC 200223 ILJ 695 (LAC) para 49; Johnson \& Johnson (Pty) Ltd v CWIU 199920 ILJ 89 (LAC) para 41; Minister of Justice and Constitutional Development $v$ Tshishonga 200930 ILJ 1799 (LAC) para 18. Davis JA in the last mentioned case stated that in determining the amount of compensation the degree of humiliation and indignity suffered by the employee should guide the court in the exercise of its discretion.

80 Vettori 2012 PELJ 231. The author indicates that punishment might have been envisaged when the legislator decided to set a higher maximum award limit for automatically unfair dismissals as the reasons for these types of dismissals are "morally reprehensible and repulsive to our sense of justice". 
reputation that the respective victims enjoy. ${ }^{81}$ There is consequently no material difference between these remedies. ${ }^{82}$

The judge in the SBV Services (Pty) Ltd case felt that the CCMA arbitrator had failed properly to explain the implications of the remedy of compensation before making his award for the payment of compensation in the amount of nine months' pay. ${ }^{83}$ What a proper explanation would entail is unclear, as there are no universally accepted norms evident from the way in which compensation awards are made in South African courts.

\subsubsection{The quantum of a compensation award}

Particularly in the earlier South African decisions, ${ }^{84}$ the English approach was followed, which dictates that an unfairly dismissed employee should be compensated only for the financial loss that he or she had suffered resulting from the unfair treatment. ${ }^{85}$ This usually meant that compensation would not exceed an amount equal to a month's notice. ${ }^{86}$ The practice of awarding small compensation amounts has become entrenched.

The application of this adopted principle is evidenced clearly in cases dealing with the unfair termination of a fixed term contract: the employees are usually awarded only an amount equal to their pay for the remainder of the term of the appointment. The dismissed employee is also required to attempt to mitigate the loss suffered by seeking alternative employment

81 In terms of $\mathrm{S} 9$ of the Constitution everyone has equal rights before the law. S 10 of the Constitution determines that "everyone has the right to have their dignity respected and protected" and s 39(1) requires courts to promote the values which form the basis of a democratic society - "human dignity, equality and freedom". Also see Minister of Justice and Constitutional Development v Tshishonga 200930 ILJ 1799 (LAC) para 18.

82 Viljoen v Nketoana Local Municipality 200324 ILJ 437 (LC) 447C-D.

83 SBV Services (Pty) Ltd case paras 42-43.

84 Ferodo (Pty) Ltd v De Ruiter 199314 ILJ 974 (LAC) 981C-981G; Amalgamated Beverage Industries $v$ Jonker 199314 ILJ 1232 (LAC). Both of these decisions were made before the enactment of the current LRA. But, more recently, in Pretoria Society for the Care of the Retarded v Loots 199718 ILJ 981 (LAC) 989-991 the court also required proof of the financial loss suffered. The aim of compensation in terms of the LRA, in the court's view, should be to place the applicant in the position he or she would have been in in the absence of the unfair act, not to punish the guilty party.

85 Lewis, Sargeant and Schwab Employment Law 446-447. See also Addis $v$ Gramophone Co Ltd 1909 AC 488; Dietman v London Borough of Brent 1987 IRLR 167; Boyo v London Borough of Lambeth 1995 IRLR 50.

86 Particularly in respect of dismissals that are found to be only procedurally unfair, paying the employee the amount that would be required to give proper notice is considered as being adequate in order to remedy the irregularity in the termination of the employee's services. 
while the unfair dismissal dispute is resolved. ${ }^{87}$ If other employment is taken up by the employee, the amounts of payment received from the new employer would be subtracted from a compensation award made for the unfair dismissal. ${ }^{88}$ Although the LRA expressly determines that a compensation award is made in addition to any other amount which an employee would legally be entitled to claim, ${ }^{89}$ any amount that had been paid as severance pay by an employer who had dismissed a fixed term employee for operational reasons would also be subtracted from a subsequent compensation award amount. ${ }^{90}$ This way of dealing with compensation has also become conventional.

No minimum compensation amount is set in the legislation. ${ }^{91}$ This makes it very difficult for legal practitioners to estimate what reasonable fees would be. In addition, it makes it almost impossible for lawyers to predict the outcome of labour disputes, and for them to advise clients accordingly. If commissioners are required to explain the possible consequences attached to making a compensation award, this is something that in my opinion also needs to be explained.

Although it is in principle possible to claim additional civil damages, the statutory restriction in section 194 of the LRA extends beyond the doors of

87 Foodpiper CC t/a Kentucky Fried Chicken v Shezi 199314 ILJ 126 (LAC) 136C.

88 Lewis, Sargeant and Schwab Employment Law 446-447. Johnson \& Johnson (Pty) Ltd v CWIU 199920 ILJ 89 (LAC) para 41; Minister of Justice and Constitutional Development $v$ Tshishonga 200930 ILJ 1799 (LAC) para 18. Davis JA determined that the court is guided by jurisprudence relating to the award of solatium in terms of the actio iniuriarum. Factors considered in determining the amount of compensation which would be just and equitable include the degree of humiliation and indignity suffered by the employee. The award determined ultimately falls within the discretion of the court.

89 Section 195 of the LRA.

90 Section 41 of the Basic Conditions of Employment Act 75 of 1997 determines that an employee dismissed for operational reasons is entitled to severance pay in the amount of one week's wages for every completed year of work, save in circumstances where the employer offers reasonable alternative work. However, see Chiloane v Rema Tip Top Industries (Pty) Ltd 200211 BLLR 1066 (LC); Khumalo v Supercare Cleaning 20008 BALR 892 (CCMA) 897D-897F; SACCAWU obo Makubalo v Pro-Cut Fruit \& Veg 20025 BALR 543 (CCMA) 545E, in which it was confirmed that fixed term employees are not entitled to "additional" severance pay. In Nkopane $v$ IEC 200728 ILJ 670 (LC) para 80 the court expressly held that severance payments ought to be subtracted from the compensation amount awarded to the fixed term employee. Also see Grogan Dismissal 637.

91 This is distinguishable from the situation in Korea, where courts are not permitted to award less compensation than the amount that the employee would have been paid for the period between the date of dismissal and the date of the order. See art 30(3) of the Labour Standards Act 5309 of 1997. In the UK there is also a basic compensation award for unfair dismissal. See s 123(3) of the Employment Rights Act, 1996. 
the Labour Courts in the absence of a specific provision allowing for further claims in the contract of employment. ${ }^{92}$ In other words, if the employer and the employee did not include a stipulation in the contract of employment which specifically provides access to the civil courts in a case of a breach of contract which would also be a dismissal, the remedies provided in the LRA would be such an employee's only recourse. ${ }^{93}$

The statutory compensation remedy lacks clout and fails to provide sufficient protection to employees. Even if the maximum amount of compensation is awarded, employees could still not recover the loss that they actually suffered resulting from the unfair treatment.

In SBV Services (Pty) Ltd the CCMA commissioner originally made an award of nine months compensation, but the Labour Court failed to consider whether the compensation award that was made would be a fair and just amount of compensation if it were found after the hearing of evidence that compensation was the correct remedy. Should the employee after having gone through the Labour Court's review proceedings and another arbitration session at which the commissioner explained the legal concepts to him again elect compensation, the maximum award that could be made would be for twelve months' remuneration as pay. This would definitely not cover the losses that the respondent had suffered considering the delay that had been caused by the review. In addition, it would be very difficult to explain an increase in the original compensation award when the commissioner had already applied his mind and thought that nine months' pay as compensation would be appropriate. ${ }^{94}$

\subsubsection{The test to be used to determine the quantum}

There does not seem to be any certainty in how the quantum of a compensation award is arrived at. What the test is that should be applied has been interpreted in different ways.

Claims for compensation in terms of the LRA more closely resemble delictual claims than they do contractual ones. ${ }^{95}$ In Camdons Realty (Pty)

SA Maritime Safety Authority v McKenzie 201031 ILJ 529 (SCA).

SA Maritime Safety Authority v McKenzie 201031 ILJ 529 (SCA) paras 25-27.

SBV Services (Pty) Ltd case para 2.

95 Contractual damages are purely pecuniary. The aim is to place the innocent party in the position that he or she would have been in if no breach of contract had occurred. Non-patrimonial damages, or psychological damages, usually need to be claimed delictually. Alert Employment Personnel (Pty) Ltd v Leech 199314 ILJ 655 (LAC) 
Ltd $v$ Hart96 the term "compensation" was defined as a payment to the victim "to make amends for a wrong that has been inflicted". 97 In Chotia $v$ Hall Longmore \& Co (Pty) Ltd ${ }^{98}$ the court indicated that "compensation" is an amount of money that is paid for something which is lost. The fact is that employees who were unfairly dismissed do not have to prove their actual losses. ${ }^{99}$

Section 194 of the LRA does not specify that compensation should cover only financial losses. In some instances sentimental damages have been awarded in unfair dismissal cases. This is done in order to compensate the aggrieved employee for emotional distress suffered. ${ }^{100}$ Section 194 of the LRA requires that the amount of compensation awarded to a successful employee-litigant in unfair dismissal cases must be determined on terms that are just and equitable and that the award amount must be less than or equal to the prescribed maximums. ${ }^{101}$

In the exercise of his or her judicial discretion, the presiding officer must take into account all relevant factors. Section 194(1) applies to all dismissals unfair due to the reason of or for the procedure followed, or both the reason and process. However, different factors are applied by the courts when deciding on the amount of compensation to be awarded for these different sub-divisions. ${ }^{102}$ Various factors have also been laid down for arbitrators to consider when deciding on what remedy is appropriate in the particular circumstances. ${ }^{103}$ The Labour Court failed to consider any of these factors before referring the matter back to the CCMA.

661C; Ferodo (Pty) Ltd v De Ruiter 199314 ILJ 974 (LAC) 981C-G; Mischke 2005 CLL 24. See also Christie Law of Contract 521.

96 Camdons Realty (Pty) Ltd v Hart 199314 ILJ 1008 (LAC).

97 Camdons Realty (Pty) Ltd v Hart 199314 ILJ 1008 (LAC) 1018.

98 Chotia v Hall Longmore \& Co (Pty) Ltd 19976 BLLR 739 (LC) 745A-745C.

99 National Union of Metalworkers of Southern Africa $v$ Precious Metal Chains (Pty) Ltd 19978 BLLR 1068 (LC) 1073J-1075J; Johnson \& Johnson (Pty) Ltd v CWU 199920 ILJ 89 (LAC) para 37; Minister of Justice and Constitutional Development $v$ Tshishonga 200930 ILJ 1799 (LAC) para 41.

100 See for instance Ferodo (Pty) Ltd v De Ruiter 199314 ILJ 974 (LAC) 981C-H; Nieuwenhuis v Group Five Roads 200021 ILJ 2074 (LC) paras 90, 98; Woolworths (Pty) Ltd v Whitehead 200021 ILJ 571 (LAC) paras 46, 51.

101 Tshongweni v Ekurhuleni Metropolitan Municipality 201233 ILJ 2847 (LAC) para 31; Kylie v CCMA 201031 ILJ 1600 (LAC) para 52.

102 Cohen 2003 ILJ 741.

103 Ferodo (Pty) Ltd v De Ruiter 199314 ILJ 974 (LAC) 981C-G; Kemp t/a Centralmed v Rawlins 200930 ILJ 2677 (LAC) 2687F-2688E. 


\subsection{The implications of "reinstatement"}

Reinstatement does not mean that a new contract is concluded. It means that the employer restores the situation that existed before the dismissal had occurred. In other words, the employee will again be in the position that he or she had previously filled and will perform the same functions on the same terms as previously. ${ }^{104}$

If a dismissal is found to have been substantively unfair and the presiding officer decides that reinstatement is the appropriate remedy in the circumstances, the employee should automatically be paid "back-pay". Put differently, such an employee should receive payment for the time that he or she had not been allowed to work and, consequently, to receive remuneration from the date of his or her dismissal. ${ }^{105}$ But it could be more complicated: The employee would also be entitled to any other payments which would have befallen him or her if the unfair dismissal had never taken place. This would have to be added to any amount that he or she would have received for the time that the employee had been prevented from working due to the unfair dismissal. It would be irrelevant in as far as the calculation of this amount of compensation is concerned whether or not the employee had made any effort to mitigate his or her losses by finding other work.

\subsubsection{A right to reinstatement}

In SBV Services (Pty) Ltd the Labour Court's argument was that if an employee's dismissal is found to have been substantively unfair, he or she is entitled to reinstatement unless that right has been waived. This could be done only if the employee, as in this case, elected compensation as the remedy instead of reinstatement. But the court, with reference to Ex parte Parfitt, ${ }^{106}$ said that this kind of waiver would be valid only if it had been done intentionally, and on an informed basis. ${ }^{107}$ This is not what section 193(2) of the LRA says. If continued employment would be intolerable or if it has become impracticable to take the unfairly dismissed employee back into the post that he or she had previously filled, compensation should be ordered. ${ }^{108}$ It is not only the employee who has to be considered. South

\footnotetext{
Nel v Oudtshoorn Municipality 201334 ILJ 1737 (SCA) para 9.

Sejake v Naledi Municipality 201435 ILJ 500 (LC).

Ex parte Parfitt 19543 SA 894 (O) 896H-97F.

SBV Services (Pty) Ltd case paras 34-35.

108 Determining whether or not this is the case is left to the presiding officer to assess. See Mzeku v Volkswagen SA (Pty) Ltd 200122 ILJ 1575 (LAC) paras 77-79. This position can be distinguished from that in Spain (arts 55(4), 56 of the Estatuto de Los
} 
Africa's labour legislation is not solely concerned with the attainment of fairness for employees. The interests of employers are equally pertinent to ensuring a sound economy. ${ }^{109}$

In the judgment it is stated that it would not be realistic to expect an employee to understand the implication of the waiver of the right to reinstatement in the absence of assistance. ${ }^{110}$ Nevertheless, the Labour Court did little to clarify the legal position concerning proper interpretation of this term.

\subsubsection{Reinstatement is not always made restrospective}

Reinstatement may not always include back-pay, and it has been held at least once in the LAC that retrospective reinstatement is not a right that an employee has. ${ }^{111}$ The court or the arbitrator has discretion to decide on whether reinstatement will be made retrospective and on the degree of retrospectivity. Although it has been accepted by our courts that the institution of an unfair dismissal action has the effect of sustaining the employment relationship, ${ }^{112}$ often awards are not made with retrospective force. ${ }^{113}$ This would usually be the case in instances where upon the facts it is evident that at least some blame for the termination of employment should be placed on the employee. ${ }^{114}$

Therefore, the summary that is provided in paragraph 45 of the SBV Services (Pty) Ltd case is completely inadequate, in particular paragraph 45.2 thereof.

Trabajadores of 1996), where employers may choose between paying compensation or reinstatement when it has been found that they unfairly dismissed an employee. This seems to be a better option than leaving it to a commissioner to explain to an employee, who is then required to make an informed decision. Arguably, employers are in a better position to understand the business implications of reinstating a particular individual.

109 Section 23 of the Constitution applies to both employers and employees. NEHAWU v University of Cape Town 20033 SA 1 (CC) paras 40-41; Van Rensburg v Austen Safe Co 199819 ILJ 158 (LC) 170F-G. See also Vettori 2012 PELJ 102.

110 SBV Services (Pty) Ltd case para 39.

111 Kroukam v SA Airlink (Pty) Ltd 200526 ILJ 2153 (LAC) para 127.

112 See for instance NAAWU (now NUMSA) v Borg-Warner SA (Pty) Ltd 199415 ILJ 509 (A) 515F-515G, 518B-518C.

113 Section 193(1)(a) of the LRA does not indicate that reinstatement needs to be made retrospective to the date of dismissal; Tshongweni $v$ Ekurhuleni Metropolitan Municipality 201233 ILJ 2847 (LAC) para 37. Also see Grogan Dismissal 619, in which the author states that reinstatement need not be retrospective in full to the date of dismissal. Whether and if so to what extent reinstatement is made retrospective is left to the presiding officer to decide.

114 Grogan Dismissal 619. 


\subsection{The meaning of "back-pay"}

The court in SBV Services (Pty) Ltd $v$ CCMA ${ }^{115}$ noted that in legal parlance "back-pay" is synonymous with damages resulting from loss of income, or constitutional damages ${ }^{116}$ or compensation in terms of the Promotion of Administrative Justice Act. ${ }^{117}$ However, the court held that the term also previously had another meaning in layman's terms. Apparently a practice existed allowing for employers to keep some of the earnings belonging to black factory workers who did not have bank accounts, and then upon closing at the end of the year to pay out these savings to the employees together with any bonuses earned. This was also called back-pay. ${ }^{118}$

The Labour Court acknowledged that certain incongruences exist in as far as the interpretation of the nature and application of reinstatement as a remedy is concerned. This is true particularly in respect of the entitlement to back-pay. The court described three divergent views regarding backpay: ${ }^{119}$ first, the order of back-pay could be made subject to the limits set in section 193 of the LRA - either twelve months' pay or 24 months' pay as remuneration, depending on whether or not the dismissal is recognised as one which is automatically unfair. ${ }^{120}$ Second, back-pay can be considered as being separate and additional to the amount of compensation that can be awarded. This would mean that the total amount awarded to the employee would not be restricted to twelve months' remuneration or two years' pay as the case may be. An employee, in terms of this perspective, would be entitled to claim whatever he or she would have earned in the time between the unfair dismissal and the finalisation of the dispute by the making of the order of reinstatement. ${ }^{121}$ Third, there is the argument that back-pay has nothing to do with reinstatement as a remedy and that reinstatement has bearing only on the right to return to one's post. ${ }^{122}$

\footnotetext{
115 SBV Services (Pty) Ltd v CCMA 201334 ILJ 996 (LC).

116 SBV Services (Pty) Ltd case para 37. Also see Jayiya v MEC for Welfare, Eastern Cape 20042 SA 611 (SCA) para 10.

117 Promotion of Administrative Justice Act 3 of 2000.

118 SBV Services (Pty) Ltd case para 37.

119 SBV Services (Pty) Ltd case para 36.

120 Zondo JP (as he was then) in Kroukam v SA Airlink (Pty) Ltd 200526 ILJ 2153 (LAC) paras 121-130.

121 Davis AJA (as he then was) in Kroukam v SA Airlink (Pty) Ltd 200526 ILJ 2153 (LAC) paras 44, 53.

122 Equity Aviation Services (Pty) Ltd v CCMA 200829 ILJ 2507 (CC) para 36.
} 
In Kroukam $v$ SA Airlink (Pty) Ltd'123 the majority of the judges in LAC expressed the view that even if a labour matter takes many years to resolve, an employee should in principle be able to claim an unlimited amount of back-pay if an order of reinstatement is made. A different course was followed in Chemical Workers Industrial Union $v$ Latex Surgical Products (Pty) $L t d,{ }^{124}$ where the court said that the minority in Kroukam was correct in remarking that the amount has to be made subject to the restrictions that are set for either an ordinary or an automatically unfair dismissal, depending on the facts. ${ }^{125}$ But in both these cases the courts had ordered back-pay in an amount that did not exceed the statutory limits in any event.

In Republican Press (Pty) Ltd v CEPPWAWU ${ }^{126}$ the employees had been dismissed more than six years before the matter was heard by the Labour Court. The SCA held that the decision in Latex had been wrong. The judges concurred on the fact that the LRA draws a distinction between reinstatement and compensation and that back-pay which flowed from reinstatement was something different from compensation. In principle, a reinstatement order can be made retrospective to the date of dismissal, regardless of the amount of time that had lapsed since the date of dismissal. However, the delay in finalisation plays a major role, and so it should, in deciding whether or not reinstatement is the appropriate remedy to be considered. ${ }^{127}$

The court in Republican Press (Pty) Ltd v CEPPWAWU ${ }^{128}$ remarked that the reason that no limitation had been placed in cases of reinstatement and its retrospectivity is probably because the legislature did not contemplate that labour disputes would take so long - longer than twelve months - to resolve. The court also expressed the view that if there were a delay in resolving a dispute, particularly if it could not be attributed to the employer, the courts would usually not make an order exceeding twelve months remuneration as far as back-pay was concerned. This view of the

\footnotetext{
123 Kroukam v SA Airlink (Pty) Ltd 200526 ILJ 2153 (LAC).

124 Chemical Workers Industrial Union v Latex Surgical Products (Pty) Ltd 200627 ILJ 292 (LAC).

125 Chemical Workers Industrial Union v Latex Surgical Products (Pty) Ltd 200627 ILJ 292 (LAC) paras 112-114.

126 Republican Press (Pty) Ltd v CEPPWAWU 200728 ILJ 2503 (SCA).

127 Grogan Dismissal 613-614, 617.

128 Republican Press (Pty) Ltd v CEPPWAWU 200728 ILJ 2503 (SCA) para 20.
} 
court in Republican Press was supported in the Equity Aviation-case, this time in the Constitutional Court. ${ }^{129}$

In Shoprite Checkers (Pty) Ltd $v$ CCMA ${ }^{130}$ the Labour Appeal Court considered it unfair not to make the award of reinstatement retrospective in a case where it considered the prejudice that the employee had suffered from being unemployed far worse than the reason for which he had been dismissed. In this case, the employee had caught eating stolen food. The court ordered the employer to reinstate the employee who had worked for Shoprite for more than 30 years before his dismissal, ${ }^{131}$ and to pay backpay to him in the amount of two years' salary.

In Billiton Aluminium SA Ltd t/a Hillside Aluminium $v$ Khanyile ${ }^{132}$ the Constitutional Court had to consider whether systemic delays in the dispute resolution system of the LRA entitles the parties to the dispute to the right for constitutional remedies to be fashioned. The employer's argument was that there had been an excessive delay of more than eight years in the resolution of the dispute and that it would prejudice the employer tremendously if an order of reinstatement were to be made retrospectively up to the date on which the dismissal had occurred. The Constitutional Court found no reason to intervene, as the delay had been caused by the employer in an attempt to resist the original reinstatement order by taking the matter on review twice during the arbitration proceedings. 133

129 Equity Aviation Services (Pty) Ltd v CCMA 200829 ILJ 2507 (CC).

130 Shoprite Checkers (Pty) Ltd v CCMA 200812 BLLR 1211 (LAC).

131 It should be noted that an employee's service record and age is not a factor that is considered by the court as a matter of course in determining what remedy is appropriate where it is found that he or she had been unfairly dismissed. The fact that it had been considered relevant in this case should be viewed as the exception rather than the rule. This is distinguishable from the position in Germany, where age is an important consideration when courts decide which remedy is most appropriate and also when determining in what amount of compensation should be paid. The chance that employees are able to find alternative employment diminishes as they get older, but this important factor is not considered by South African courts when determining what remedy is most appropriate or when deciding what amount of compensation should be awarded. In so far as the size of compensation awards go, the limit that is set for an award is higher for older employees who have worked for longer. S 10 of the Protection Against Dismissal Act, 1969. Also see s 1(3) of the Protection against Dismissal Act, 1969, which applies to retrenchments. In this provision, factors like social conditions, age and term of employment are included under those to be considered before deciding if a person should be retrenched in the first place.

132 Billiton Aluminium SA Ltd t/a Hillside Aluminium v Khanyile 20105 BLLR 465 (CC).

133 Billiton Aluminium SA Ltd t/a Hillside Aluminium v Khanyile 20105 BLLR 465 (CC) paras 51-52. 


\subsection{Legal costs}

Employers seem to be willing to pay large amounts of legal costs in order to oppose employees' claims in the labour forums. For instance, the Labour Court in Gubevu Security Group Pty Ltd and Ruggiero ${ }^{134}$ noted that the employer in this particular case by taking the matter on review to the Labour Court had chosen to incur legal costs that well exceeded the amount of compensation that the arbitrator had originally ordered it to pay to the employee. ${ }^{135}$

Employers are in a better financial position to pay legal costs than dismissed employees with no income. ${ }^{136}$ While a labour dispute is pending, South African employees cannot return to their posts and work. ${ }^{137}$ As a result, costs awards that are made against employees or orders that employees settle their own costs are often more vexing for employees. ${ }^{138}$ Employers are more likely to have legal representatives than employees. ${ }^{139}$ In terms of the Labour Court Rules, one advocate and one attorney may be employed for the purposes of a labour dispute, although allowance is made, upon application, for the payment of fees for additional advocates and attorneys. ${ }^{140}$ The costs must be taxed according to the court order ${ }^{141}$ or an agreement reached between the parties, otherwise the High Court tariff applies. ${ }^{142}$ Attorneys and advocates often rely on contingency fees when representing employees in unfair dismissal

134 Gubevu Security Group Pty Ltd and Ruggiero 201233 ILJ 1171 (LC).

135 Gubevu Security Group Pty Ltd and Ruggiero 201233 ILJ 1171 (LC) paras 27-29.

136 Department of Labour 2012 https://www.labour.gov.za/downloads/legislation/ bills/proposed-amendment-bills/memoofobjectslra.pdf 18. It is noted that "the primary reason for providing statutory protection against unfair dismissal and for providing remedies for unfair dismissal as a species of unfair labour practice, is the inequality of bargaining power between employer and employee". Also see Kylie v CCMA 2010 31 ILJ 1600 (LAC) para 41.

137 Notably in Germany employees can continue working during the dispute resolution process. This ensures that any payment made as compensation serves its purpose. It does not become, as is the case in South Africa, a penance for the loss of income suffered by the unfairly dismissed employee. See s 102 of the Works Constitution Act, 2001.

138 Section 162 of the LRA confers discretion on this court to make orders for costs based on the requirements of law and fairness.

139 Netherburn Engineering CC t/a Netherburn Ceramics v Mudau 200323 ILJ 1712 (LC) 1719.

140 Rules 24(1) and (2) of the Labour Court Rules.

141 As there are no Labour Court scales for taxation, costs in the Labour Court are taxed according to the tariffs used in the High Court. See Rule 48 of the Uniform Rules of the High Court.

142 Rule 24(3) of the Labour Court Rules. 
disputes. ${ }^{143}$ Legal representatives are entitled to a contingency fee of a maximum of only 25 per cent of the total amount of compensation and actual costs incurred. ${ }^{144}$

According to a 2010 study, it was estimated that the fee for drafting an application to the Labour Court amounts to about R7 000. The costs for having legal representatives, according to the assessment, amount to R26 000 for the first day in court, and for additional court days approximately R12 000 per day is payable. ${ }^{145}$ This excludes additional fees that may be payable on an attorney and client basis and attorney and own client costs such as consultation fees, attendance and perusal costs, drafting and drawing costs of subsequent pleadings, and miscellaneous and travel expenses. ${ }^{146}$

Ordinarily a successful litigant would be entitled to recover the costs incurred by him or her for approaching a court in order to enforce his or her right from the unsuccessful litigant on a party and party basis. This is not always what happens in labour disputes as costs will not always follow the result. Presiding officers are afforded a wide discretion when it comes to ordering the payment of legal costs. Ultimately the decision is made in accordance with what is considered to be fair in terms of the law. ${ }^{147}$ This is also evident in the case under consideration: Although the Labour Court agreed with the main finding that the dismissal was unfair (the employer lost) the unfairly dismissed employee was nevertheless ordered to pay his own costs for the review. ${ }^{148}$

143 Section 2 of the Contingency Fees Act 66 of 1997 permits the use of contingency fee agreements in regulation of amounts that legal representatives may charge if they work on a no win-no fee basis.

144 See generally De la Guerre $v$ Ronald Bobroff and Partners Incorporated '[2013] ZAGPPH 33 (13 February 2013). Although the dispute here was not a labour dispute, the Contingency Fees Act 66 of 1997 is of equal application in labour disputes.

145 Benjamin and SBP 2010 http://www.labour.gov.za/DOL/downloads/documents/ useful-documents/labour-relations/RIA13Sept2010.pdf 114.

146 Rules 69 and 70 of the Uniform Rules of Court: Rules Regulating the Conduct of the Proceedings of the Several Provincial and Local Divisions of the High Court of South Africa (High Court Rules) and the items and fees indicated therein for the calculation of costs.

147 Section 162(1) of the LRA. Gubevu Security Group Pty Ltd and Ruggiero 201233 ILJ 1171 (LC) para 28. See also Apollo Tyres South Africa (Pty) Ltd v CCMA 20135 BLLR 434 (LAC) para 62. The court held that the employer had acted in a deplorable manner towards the employee and accordingly it was held that the employer "ought to be mulcted in costs."'

148 SBV Services (Pty) Ltd case para 48(b) and (c). 
If the employee in the SBV Services (Pty) Ltd case, after hearing the commissioner's explanation of the various remedies, opts for reinstatement, a huge chunk of any back-pay that the commissioner may (or may not) award would go towards the payment of legal fees.

\subsection{Creation of another ground for review}

It is possible for either party in a labour dispute to refer a final award made by an arbitrator on review to the Labour Court. ${ }^{149}$ Reviews obviously delay bringing labour disputes to their conclusion. Consequently, the LRA, which propagates for expedient resolution of labour disputes, ${ }^{150}$ intended for review proceedings to be exceptional and not to be the norm, as they have become. ${ }^{151}$ Arbitration awards were supposed to be final and binding, not to serve as the first of many steps in resolving labour disputes. This practice has a very detrimental effect on the attainment of justice. ${ }^{152}$

It is trite that ignorance of the law (ignorantia juris non excusat) is not a defence. It is also not generally an accepted ground to overturn an award. ${ }^{153}$ Employees are usually bound by the contracts that they conclude even if they do not fully understand the nature of the agreement that they had signed. ${ }^{154}$ To set a requirement that an employee should be

149 This is possible in terms of either ss 145 or 158 of the LRA. S 145(2) sets out certain grounds upon which legal matters would be reviewable: misconduct by the commissioner in performance of his or her duties, gross irregularity in the proceedings, or exceeding of his or her powers by the commissioner or that the award was otherwise obtained in an irregular way. S 158(g) extends the scope to make any function performed under the LRA reviewable. Despite this seemingly blanket concept, it is in my opinion a further and uncalled for extension that is required here.

150 The main purpose for establishing the CCMA was to promote inexpensive and quick resolution of labour disputes. This aim supports the purpose of the LRA as set out in $s$ 1(d)(iv) thereof: to promote the effective resolution of disputes. See Shoprite Checkers (Pty) Ltd v CCMA 20097 BLLR 619 (SCA) para 34; Vorster v Rednave Enterprises CC t/a Cash Converters Queenswood 200930 ILJ 407 (LC) 411; Netherburn Engineering CC t/a Netherburn Ceramics v Mudau 20102 SA 269 (CC) paras 12-13; Bezuidenhout $v$ Johnston 200627 ILJ 2337 (LC) para 26. See also Chillibush Communications (Pty) Ltd v Gericke 201031 ILJ 1350 (LC) para 19. Unfortunately, the CCMA has failed to live up to the high expectations. See Bhorat and Cheadle 2010 http://www.dpru.uct.ac.za/sites/defaults/files.site/default/files/DP RU\%20PB\%2010-27.pdf 26.

151 Shoprite Checkers (Pty) Ltd v CCMA (LAC) para 28. Benjamin and Gruen Regulatory Efficiency of the CCMA paras 81-82.

152 Van Niekerk 2007 http://www.dpru.uct.ac.za/sites/default/files/image_tool/images/36/DPRU\%20WP07119.pdf 19.

153 S v De Blom 19773 SA 513 (A).

154 See for instance Dladla and On-Time Labour Hire CC 200627 ILJ 216 (BCA); Foster v Stewart Scott Inc 199718 ILJ 367 (LAC) 372. 
"informed" before making an election between re-instatement or compensation would mean that employees can raise their ignorance as a ground for review.

\subsection{Reasons have to be adduced before the Labour Court can overturn a CCMA award}

In Edelweiss Glass and Aluminium (Pty) Ltd $v$ NUMSA ${ }^{155}$ the Labour Appeal Court, with reference to the Labour Appeal Court's decision in $\mathrm{Dr}$ DC Kemp t/a Centralmed $v$ Rawlins, ${ }^{156}$ stressed that it would be in a position to intervene and overturn a decision taken within the Labour Court's discretion only if it is shown that the Labour Court erred/misdirected itself in the exercise of the judicial discretion that is afforded to it. Having found that the Labour Court had been correct, and that the judgment had not been improperly attained, Jappie JA dismissed the appeal ordering the employer to pay the costs. ${ }^{157}$ If the principle laid down by the court is applied to the SBV Services (Pty) Ltd case, clearly the presiding officer had erred in overturning the award that had been made by the CCMA commissioner without considering whether not the employee but the commissioner had applied his mind to the facts properly in assessing what remedy is most appropriate.

There have been instances when the remedy has been changed from one for reinstatement to an order to pay compensation too. For instance, in First National Bank - A Division of First Bank Ltd v Language ${ }^{158}$ the employee had accused the bank of falsifying documents, of having stolen his money, of being unscrupulous and of lacking good faith. These accusations were in the court's view so grave that they contributed, along with the serious contravention that the employee had been found guilty of, to a break-down in the employment relationship that rendered reinstatement impracticable. The court consequently set aside the order of reinstatement that had been made by the Labour Court and replaced it with an award of compensation. Another example is one where the employees were reinstated but they were no longer able to perform their

\footnotetext{
155 Edelweiss Glass and Aluminium (Pty) Ltd v NUMSA 201132 ILJ 2939 (LAC) para 57.

156 Dr DC Kemp t/a Centralmed v Rawlins 200911 BLLR 1027 (LAC).

157 Edelweiss Glass and Aluminium (Pty) Ltd v NUMSA 201132 ILJ 2939 (LAC) para 58.

158 First National Bank - A Division of First Bank Ltd v Language 201334 ILJ 3103 (LAC).
} 
duties. In that case the Labour Court found that the employer was not obliged to comply with the CCMA award. ${ }^{159}$

Although it should be permissible to take a CCMA commissioner's award regarding the remedy afforded for an unfair dismissal on review, it is in my opinion, in the same vein as in the Edelweiss case above, only in exceptional circumstances that the prayer to overturn the award should be granted. It should not be possible for the Labour Court to interfere with the exercise of the commissioner's discretion without cogent reasons being adduced from the record that was produced in the CCMA.

\section{Conclusion}

In my opinion this case should not have been referred back to the CCMA. The interpretation provided to sections 193 and 194 of the LRA in this decision could result in unfairness: giving employees a second bite at the cherry could be unfair in disputes that take long to resolve. This would often be the case in matters like the present one that have been taken on review.

On the other hand, the vagueness regarding the possibility of exceeding the statutory maximum when making a reinstatement order retrospective could result in unfairness for employers as well. But even if an award which exceeds the twelve month statutory cap on compensation is ultimately made, the employee's litigation costs - incurred despite the fact that he had not initiated the review proceedings - could still potentially outweigh the remedy.

If a legal representative ${ }^{160}$ was unable to explain properly the legal principles pertaining to the different remedies and their application to the client, should it be expected from a CCMA commissioner? Even the court's explanation of the concepts is in my opinion at times incoherent and inchoate.

It would appear that by trying to set out rather rigid guidelines in a broadbrush manner, the Labour Court in the SBV Services (Pty) Ltd case has left arbitrators with more questions than answers concerning the proper way to deal with remedies for unfair dismissal.

159 See for instance Independent Municipal \& Allied Trade Union obo Erasmus $v$ City of Johannesburg 201334 ILJ 1741 (LC).

160 From the reported judgment it is apparent that Webber Wentzel represented the Appellant in this case. This firm of attorneys clearly did not anticipate that the appellant would not succeed, judging from this particular point of review. 


\section{Bibliography}

\section{Literature}

Benjamin and Gruen Regulatory Efficiency of the CCMA

Benjamin P and Gruen G The Regulatory Efficiency of the CCMA: A Statistical Analysis of the CCMA's CMS Database (University of Cape Town Cape Town 2006)

Christie Law of Contract

Christie RH The Law of Contract in South Africa $5^{\text {th }}$ ed (LexisNexis Butterworths Durban 2006)

Cohen 2003 ILJ

Cohen T "Exercising a Judicial Discretion - Awarding Compensation for Unfair Dismissals" 2003 ILJ 739

Dimatteo 1997 SC L Rev

Dimatteo LA "The Counterpoise of Contracts: The Reasonable Person Standard and the Subjectivity of Judgment" 1997 SC L Rev 293-355

Friedman et al Tokiso Dispute Settlement

Friedman S et al Tokiso Dispute Settlement 2010 Review 2009-2010 (Juta Cape Town 2010)

Grogan Dismissal

Grogan J Dismissal $2^{\text {nd }}$ ed (Juta Cape Town 2014)

Grogan 2015 EL

Grogan $\mathrm{J}$ "Reinstatement Means Just That: Resuming Employment after Unfair Dismissal" 2015 Feb EL 11

Lewis, Sargeant and Schwab Employment Law

Lewis D, Sargeant M and Schwab B Employment Law: The Essentials $11^{\text {th }}$ ed (Chartered Institute of Personnel and Development London 2010)

Mischke 2005 CLL

Mischke "Calculating Compensation for Unfair Dismissal: Quantifying Just and Equitable Compensation" 2005 CLL 24 
Van Heerden and Coetzee 2011 De Jure

Van Heerden $\mathrm{C}$ and Coetzee $\mathrm{H}$ "Minister for Justice and Constitutional Development v Tshishonga 20099 BLLR 862 (LAC): Just and Equitable Compensation for Non-patrimonial Loss" 2011 De Jure 479-489

Vettori Employment Contract

Vettori S The Employment Contract and the Changed World of Work (Ashgate Burlington 2007)

Vettori 2012 PELJ

Vettori $S$ "The Role of Human Dignity in the Assessment of Fair Compensation for Unfair Dismissal" 2012 PELJ 102-123

Vettori 2013 SA Merc LJ

Vettori S "Enforcement of Labour Arbitration Awards in South Africa" 2013 SA Merc LJ 245-254

Visser and Potgieter Law of Damages

Visser PJ and Potgieter JM Law of Damages $2^{\text {nd }}$ ed (Juta Cape Town 2009)

Waglay 2003 ILJ

Waglay B "The Proposed Re-organisation of the Labour Court and the Labour Appeal Court" 2003 ILJ 1223

\section{Case law}

Adams v Coin Security Group (Pty) Ltd 199920 ILJ 1192 (LC)

Addis v Gramophone Co Ltd 1909 AC 488

Alert Employment Personnel (Pty) Ltd v Leech 199314 ILJ 655 (LAC)

Amalgamated Beverages Industries v Jonker (Pty) Ltd 199314 ILJ 1232 (LAC)

Apollo Tyres South Africa (Pty) Ltd v CCMA 20135 BLLR 434 (LAC)

Bezuidenhout v Johnston 200627 ILJ 2337 (LC)

Billiton Aluminium SA Ltd t/a Hillside Aluminium v Khanyile 20105 BLLR 465 (CC)

Boyo v London Borough of Lambeth 1995 IRLR 50 
Camdons Realty (Pty) Ltd v Hart 199314 ILJ 1008 (LAC)

Chemical Energy Paper Printing Wood \& Allied Workers Union v Glass \& Aluminium 2000 CC 200223 ILJ 695 (LAC)

Chemical Workers Industrial Union v Latex Surgical Products (Pty) Ltd 200627 ILJ 292 (LAC)

Chillibush Communications (Pty) Ltd v Gericke 201031 ILJ 1350 (LC)

Chiloane v Rema Tip Top Industries (Pty) Ltd 200211 BLLR 1066 (LC)

Chotia v Hall Longmore \& Co (Pty) Ltd 19976 BLLR 739 (LC)

Consolidated Frame Cotton Corporation Ltd $v$ President of the Industrial Court; Consolidated Woolwashing and Processing Mills Ltd $v$ President of the Industrial Court 19863 SA 786 (A)

De la Guerre v Ronald Bobroff and Partners Incorporated '[2013] ZAGPPH 33 (13 February 2013) Dietman v London Borough of Brent 1987 IRLR 167

Dladla and On-Time Labour Hire CC 200627 ILJ 216 (BCA)

Dr DC Kemp t/a Centralmed v Rawlins 200911 BLLR 1027 (LAC)

Edelweiss Glass and Aluminium (Pty) Ltd v NUMSA 201132 ILJ 2939 (LAC)

Equity Aviation Services (Pty) Ltd v CCMA 200829 ILJ 2507 (CC)

Ex parte Parfitt 19543 SA 894 (O)

Ferodo (Pty) Ltd v De Ruiter 199314 ILJ 974 (LAC)

First National Bank - A Division of First Bank Ltd v Language 201334 ILJ 3103 (LAC)

Foodpiper CC t/a Kentucky Fried Chicken v Shezi 199314 ILJ 126 (LAC)

Foster v Stewart Scott Inc 199718 ILJ 367 (LAC)

Fouldien v House of Trucks (Pty) Ltd 200223 ILJ 2259 (LC)

Gubevu Security Group Pty Ltd and Ruggiero 201233 ILJ 1171 (LC) 
Independent Municipal \& Allied Trade Union obo Erasmus $v$ City of Johannesburg 201334 ILJ 1741 (LC)

Jabari v Telkom SA (Pty) Ltd 200627 ILJ 1854 (LC)

Jayiya v MEC for Welfare, Eastern Cape 20042 SA 611 (SCA)

Johnson \& Johnson (Pty) Ltd v CWIU 199920 ILJ 89 (LAC)

Kemp t/a Centralmed v Rawlins 200930 ILJ 2677 (LAC)

Khumalo v Supercare Cleaning 20008 BALR 892 (CCMA)

Kroukam v SA Airlink (Pty) Ltd 200526 ILJ 2153 (LAC)

Kylie v CCMA 201031 ILJ 1600 (LAC)

Lakomski v TTS Tool Technic Systems (Pty) Ltd 200728 ILJ 2775 (LC)

Masawi v Chabata 19914 SA $764(\mathrm{ZH})$

Media 24 Ltd v Grobler 200526 ILJ 1007 (SCA)

Mediterranean Textile Mills v SA Textile Workers Union 19986 BLLR 549 (A)

Mediterranean Textile Mills (Pty) Ltd v SA Clothing \& Textile Workers Union 201233 ILJ 160 (LAC)

Minister of Justice and Constitutional Development v Tshishonga 200930 ILJ 1799 (LAC)

Myers v Abrahamson 19523 SA 121 (C)

Myers v National Commissioner of the SA Police Service 2013 JOL 30564 (SCA)

Mzeku v Brand 20018 BLLR 857 (LAC)

Mzeku Volkswagen SA (Pty) Ltd 200122 ILJ 1575 (LAC)

NAAWU (now NUMSA) v Borg-Warner SA (Pty) Ltd 199415 ILJ 509 (A)

Nathan $v$ the Reclamation Group (Pty) Ltd 200223 ILJ 588 (CCMA) 
National Industrial Workers Union v Chester Wholesale Meats KZN (Pty) Ltd 200425 ILJ 1293 (LC)

National Union of Metalworkers of Southern Africa $v$ Precious Metal Chains (Pty) Ltd 19978 BLLR 1068 (LC)

NEHAWU v University of Cape Town 20033 SA 1 (CC)

Nel v Oudtshoorn Municipality 201334 ILJ 1737 (SCA)

Netherburn Engineering CC t/a Netherburn Ceramics v Mudau 200323 ILJ 1712 (LC)

Netherburn Engineering CC t/a Netherburn Ceramics v Mudau 20102 SA 269 (CC)

Nieuwenhuis v Group Five Roads 200021 ILJ 2074 (LC)

Nieuwoudt v All-Pak 200930 ILJ 2444 (LC)

Nkopane v IEC 200728 ILJ 670 (LC)

NUM v East Rand Gold \& Uranium Co Ltd 199112 ILJ 1221 (A)

NUMSA v Edelweiss Glass and Aluminium (Pty) Ltd 200911 BLLR 1083 (LC)

Pedzinski v Andisa Security (Pty) Ltd 20062 BLLR 184 (LC)

PG Group (Pty) Ltd v Mbambo 20051 BLLR 71 (LC)

Pretoria Society for the Care of the Retarded v Loots 199718 ILJ 981 (LAC)

Republican Press (Pty) Ltd v CEPPWAWU 200728 ILJ 2503 (SCA)

S v De Blom 19773 SA $513(\mathrm{~A})$

SA Chemical Workers Union v Afrox Ltd 199920 ILJ 1718 (LAC)

SA Maritime Safety Authority v McKenzie 201031 ILJ 529 (SCA)

SACCAWU obo Makubalo v Pro-Cut Fruit \& Veg 20025 BALR 543 (CCMA)

SBV Services (Pty) Ltd v CCMA 201334 ILJ 996 (LC) 
Sejake v Naledi Municipality 201435 ILJ 500 (LC)

Shoprite Checkers (Pty) Ltd v CCMA 200812 BLLR 1211 (LAC)

Shoprite Checkers (Pty) Ltd v CCMA 20097 BLLR 619 (SCA)

Sidumo v Rustenburg Platinum Mines Ltd 200728 ILJ 2405 (CC)

Solidarity obo McCabe v SA Institute for Medical Research 20039 BLLR 927 (LC)

Stevenson v Sterns Jewellers (Pty) Ltd 19867 ILJ 318 (IC)

Themba v Mintroad Sawmills 20152 BLLR 174 (LC)

Tshishonga v Minister of Justice and Constitutional Development 20074 BLLR 327 (LC)

Tshongweni v Ekurhuleni Metropolitan Municipality 201233 ILJ 2847 (LAC)

Van Rensburg v Austen Safe Co 199819 ILJ 158 (LC)

Viljoen v Nketoana Local Municipality 200324 ILJ 437 (LC)

Vorster $v$ Rednave Enterprises CC t/a Cash Converters Queenswood 200930 ILJ 407 (LC)

Woolworths (Pty) Ltd v Whitehead 200021 ILJ 571 (LAC)

\section{Legislation}

Basic Conditions of Employment Act 75 of 1997

Constitution of the Republic of South Africa, 1996

Contingency Fees Act 66 of 1997

Employment Rights Act, 1996 (United Kingdom)

Estatuto de Los Trabajadores of 1996 (Spain)

Labour Relations Act 28 of 1956

Labour Relations Act 66 of 1995 
Labour Relations Amendment Act 6 of 2014

Labour Standards Act 5309 of 1997 (Korea)

Promotion of Administrative Justice Act 3 of 2000

Protection against Dismissal Act, 1969 (Germany)

Works Constitution Act, 2001 (Germany)

\section{Government publications}

Explanatory Memorandum for the Labour Relations Amendment Bill (1995) 16 ILJ 278

Labour Court Rules

Rules of Conduct of Proceedings before the CCMA

Uniform Rules of Court: Rules Regulating the Conduct of the Proceedings of the Several Provincial and Local Divisions of the High Court of South Africa (High Court Rules)

Uniform Rules of the High Court

\section{Internet sources}

Benjamin and SBP 2010 http://www.labour.gov.za/DOL/ downloads/documents/useful-documents/labour-relations/RIA13

Sept2010.pdf

Benjamin P and SBP 2010 "Option Analysis: Protection of Atypical Employees. Assessment of Selected Provisions of the Labour Relations Amendment Bill 2010 and the Basic Conditions of Employment Amendment Bill 2010" in Benjamin P et al Regulatory Impact Assessment of Selected Provisions of the: Labour Relations Amendment Bill, 2010; Basic Conditions of Employment Amendment Bill, 2010; Employment Equity Amendment Bill, 2010 Employment Services Bill, 2010 12-49 http://www.labour.gov.za/DOL/downloads/documents/ useful-documents/labour-relations/RIA13Sept2010.pdf accessed 24 November 2014 
Bhorat and Cheadle 2010 http://www.dpru.uct.ac.za/sites/defaults/ files.site/default/files/DPRU\%20PB\%2010-27.pdf

Bhorat $\mathrm{H}$ and Cheadle H 2010 Labour Reform in South Africa: Measuring Regulation and a Synthesis of Policy Suggestions http://www.dpru.uct.ac.za/sites/defaults/files.site/default/files/DPRU\%20PB \%2010-27.pdf accessed 24 November 2014

Department of Labour 2012 https:/www.labour.gov.za/downloads/ legislation/bills/proposed-amendment-bills/memoofobjectslra.pdf

Department of Labour 2012 Memorandum of the Objects of the Labour Relations Amendment Bill, 2012 https://www.labour.gov.za/downloads/ legislation/bills/proposed-amendment-bills/memoofobjectslra.pdf accessed 24 November 2014

Van Niekerk 2007 http://www.dpru.uct.ac.za/sites/default/files/ image_tool/images/36/DPRU\%20WP07-119.pdf

Van Niekerk A 2007 Regulated Flexibility and Small Business: Revisiting the LRA and BCEA - A Response to Halton Cheadle's Concept Paper http://www.dpru.uct.ac.za/sites/default/files/image_tool/images/36/DPRU\% 20WP07-119.pdf accessed 24 November 2014

\section{List of Abbreviations}

CCMA

CLL

$\mathrm{EL}$

ILJ

LAC

LRA

PELJ

SA Merc LJ

SCA

SC L Rev
Commission for Conciliation, Mediation and Arbitration

Contemporary Labour Law

Employment Law

Industrial Law Journal

Labour Appeal Court

Labour Relations Act 66 of 1995

Potchefstroom Electronic Law Journal

South African Mercantile Law Journal

Supreme Court of Appeal

South Carolina Law Review 